\title{
THE INTERRELATION AND INTERACTION OF FINANCIAL MARKETS WITH FINANCIAL CYCLES OF THE NATIONAL ECONOMY OF RUSSIA Viktor Barkhatov $^{1}$, Ekaterina Lymar ${ }^{2}$, Ivan Koptelov ${ }^{3}$
}

\begin{abstract}
A market economy assumes the circularity of economic development. Many scholars have speculated on the existing relationship between economic and financial cycles. The emergence of financial markets in the early 20th century gave impetus to the development of the theory of financial cycles which account for financial ups and downs similarly with economic cycles. One of the most impactful areas of research of current trends in financial cycles is the study of how these are influenced by contemporary financial market tools, as this will help determine whether the basic phases of financial cycles can be reconciled. This article aims at analyzing various aspects of the relationship and the interaction of financial markets with the financial cycles of the national economy in the context of the Russian Federation. We also give consideration to the behavior of the contemporary financial system's chief players-large corporations, credit institutions, facilitating agencies, and state authorities acting as regulators of financial and economic cycles.
\end{abstract}

JEL Classification Numbers: G01, G10, G18, DOI: 10.12955/cbup.v7.1336

Keywords: financial market, financial cycle, interrelation, national economy

\section{Introduction}

A market economy assumes the circularity of economic development since it involves inflation, a business climate, law of demand, and other factors. National economies develop by way of steady or uneven growth as well as by way of oscillations, which are not random or inadvertent, but are expressive of the economy's shift from one steady condition to another.

The emergence of financial markets in the early 20th century gave impetus to the development of the theory of financial cycles, which account for financial ups and downs similarly with economic cycles.

Though the theory of financial cycles is today at its infant stage, it has been rapidly developing since the conceptual emergence of financial markets and the avowal of their significance for global economy.

Consequently, the impacts produced by contemporary financial market tools on financial cycles are now a pivotal area of research (Zarubezhnov and Koptelov, 2018).

The research methodology is based on the works of Russian and foreign scientists.

According to Borio (2015), post-crisis, macroprudential frameworks have rightly become an essential pillar of financial stability policies. He analyzes the implications of the financial cycle for their design, including objectives, instruments and governance as well as, more specifically, the strengths and limitations of macro-stress tests and network analysis. He highlights the areas where the scope for further work is greatest, including international coordination, the role of non-banks and sovereign risk. Addressing financial stability is a task that requires the active support of other policies, including monetary and fiscal policy (Borio, 2015).

Plasil and Seidler (2013) implies a need to study the financial cycle in addition to the economic cycle itself, not least because the foundations of financial risks and imbalances are laid in good economic times, when expectations are running high. An expansionary phase of the financial cycle, associated with high (or even excessive) credit growth, is often followed by a deterioration in borrowers' ability to repay, growth in non-performing loans and large losses in the banking sector, which together can limit banks' ability to lend to the sound part of the real economy (Plasil and Seidler, 2013).

Plasil and Seidler offers one of the possible methods for measuring the position of the economy in the financial cycle and to evaluate its ability to signal an impending risk of financial instability in advance. The proposed indicator takes into account the requirement that it be practically applicable in macroprudential policy-making, and especially in decision-making on the countercyclical capital buffer rate. This method formed the basis for further analysis of the financial cycles of the Russian economy.

Much of the empirical literature concerned with predicting banking crises has been focusing on developing early warning systems (EWS) which seek to predict future crises. Alessi (2012) compares the performance of nine distinct models resulting from the work of the Macroprudential Research

\footnotetext{
${ }^{1}$ Chelyabinsk State University, Russian Federation, ecoba@csu.ru

${ }^{2}$ Chelyabinsk State University, Russian Federation, lymar@csu.ru

${ }^{3}$ Chelyabinsk State University, Russian Federation, koptelov@csu.ru
} 
Network (MaRs). He evaluates the models' relative usefulness by comparing the ratios of false alarms and missed crises and discuss implications for practical use and future research (Alessi, 2012).

\section{Interrelation and interaction of financial markets with financial cycles of the national economy.}

Currently, we can identify a number of ways in which financial markets interact with and affect financial cycles within the framework of a national economy.

First, financial cycle phases reshape over the course of time, and these changes are contingent on periodic fluctuations of the capital gearing level (Lee, 2012).

This evolution of financial cycles can be explained by regular fluctuations in the level of capital leverage, which can be defined in general terms as the ratio between the assets owned by an economic agent and the level of debt incurred to obtain the said assets (Plasil and Seidler, 2013).

In practice, credit leverage can be replaced by a credit gap (the deviation in the ratio between the amount of loans and the GDP from a long-term trend, Lee, 2013). For instance, this approach is incorporated in the Basel III international capital and liquidity standards - a document adopted by the Basel Committee on Banking Supervision, which contains general recommendations in the field of banking and financial regulation (Fabozzi et al., 2010).

Credit leverage grows steadily until a financial cycle switches to a new phase: most commonly, this change occurs undisturbed, without the intervention of the state (Mishkin and Eakins, 2017). Although, in some cases, a cyclical recession may be fraught with significant financial losses and may spark a crisis.

At some point, the credit leverage begins to decrease while remaining high on the early stages of a financial crisis (given the nominal GDP drop, the credit leverage may even grow to a certain degree). This phase of decrease in the leverage ratio can last for several years, while if a crisis is severe, the capital leverage may eventually fall below its long-term equilibrium value (Mankiw, 2011). Although the capital leverage level may be nearing a turning point on both sides, the economic situation will be essentially different in each of the cases.

At the pre-crisis, optimistic stage, the credit boom endures, while after the peak is reached, the economy finds itself under financial stress and in need of state support. Since the reconciliation of capital gearing with economic conditions is usually delayed, its level of leverage needs to be limited by macroprudential policy measures at the growth stage (Alessi, 2014). In this regard, in order to effectively identify emerging risks and to take timely preventive action, the current stage of a financial cycle needs to be determined correctly. However, the record shows that the current state of an economy within a financial cycle is rather hard to assess: first, its definition is quite vague, and, second, it is a latent process unrelated to specific observable variables (Koptelov, 2017). Therefore, to conduct an empirical analysis, we need a suitable indicator that is representative of the main trends in the behavior of market players-this helps, though indirectly, define the cycle phase.

The second typical impact of financial markets on financial cycles comes from shadow banking that entails a significant risk of business instability.

Shadow banking is commonly understood as an aggregate of financial institutions that provide unlicensed banking services. This system began to actively develop in the early 2000s, and to date its extent of business is around $100 \%$ of the world's GDP. Shadow banking includes all credit operations that occur outside the official banking system.

The participants of shadow banking include structural investment companies, hedge funds, investment banks, and brokers.

The third factor that we have identified is the low volatility of financial markets that serves as a catalyst of financial crisis.

This is due to the fact that when low volatility persists over a long period of time, investors tend to assume a bigger credit leverage: they increase their debt to boost their investment, which can cause serious challenges down the line.

The structural "shoulders" associated with low realized volatility may-very likely—destabilize the economy and accelerate or, at the very least, catalyze a new financial crisis. 
The assets whose efficiency hinges on volatility come to a large amount - possibly, hundreds of billions of dollars. These funds are also owned by funds engaged in computer-modeled operations, as well as by so-called risk parity funds that aim at certain levels of exposure.

When volatility soars - which increases risk levels - it can trigger a huge volume of sales on the part of these funds. This will, in its turn, launch a self-reinforcing process, when the growth of volatility leads to bigger sales that will, again, increase volatility and provoke more sales, etc.

The fourth impact consists in the repurchase of shares by large corporations, which accounts for financial ups and downs.

By purchasing their own shares on the stock exchange, corporations create a critical imbalance. On the one hand, it deteriorates their financial condition: they often take loans to buy shares, and the interests on these loans will have to be paid. It might seem that this should undermine the value of these corporations, but it does not: conversely, it grows, since their shares are actively traded.

As a result, these corporations become overvalued, and their shares will normally depreciate after a while, unless they take new loans to repurchase them. However, the longer and the more actively this repurchase is realized, the more profound the debacle will be.

The fifth impact is the increase in the level of debt and financial risk, which provokes financial imbalance after the financial cycle recovery phase is over.

If economic agents interpret a national economy's temporary cyclical recovery as a long-term growth of labor productivity, this may instigate a new financial cycle reinforced by the increased willingness of households, business entities, and the state to use more borrowed funds to account for the growth in the total debt spent on high-risk assets (Borio, 2015). These cycles are characteristic of most developing countries, where distinguishing between long-term productivity growth (e.g., as a result of direct foreign investment) and cyclical improvements is quite problematic.

The loss of ability to adequately assess the actual level of financial risks causes further increase in the value of assets, weakens conditions for external fund raising, and provokes high investment activity supported by growth in production, overall increasing incomes and return on assets.

Financial imbalance and growing systemic risks remain undervalued after the recovery phase of a cycle is reached. Later, when the economic activity slows down under the influence of negative stimuli, these risks and imbalances begin to manifest themselves.

The economic downturn overturns the correlation - market participants realize the insufficiency of their incomes to cover excessive debts, retained assets deteriorate, and balance sheets need to be re-structured. In these circumstances, banks and their customers may, on the contrary, start showing extreme reluctance to assume new financial risks.

In fact, the processes described above are no less natural than the business cycles of the real sector. However, financial imbalances can reach critical levels, leading to the deepening and prolongation of cyclical declines in the economy's non-financial segment (Song Shin, 2013). If a situation is associated with macroeconomic uncertainty, lack of capital, low liquidity of banks, or panic divestiture of overvalued assets, a recession can start in no time and follow an especially aggressive course.

The last significant episode of financial instability, which began in 2007 and acquired global dimensions, incurred enormous macroeconomic costs: some economies will need a few more years to simply return to pre-crisis levels of production.

Figure 1 shows the correlation of the loans provided to the companies and Russia's GDP in 2007-2018. Generally, the real economy debt load of the Russian Federation has been increasing. This is a consequence of the 2007 global recession. A further marked increase in 2012-2015 is also associated with the general decline of the national economy (FSSS, 2019).

The sixth factor is connected with encouraging financial markets to behave less pro-cyclically, which is an essential goal of macroprudential policy of financial cycle regulation.

Since the 1990s, the liberalization of financial markets against the background of their high procyclicality has led to the situation, in which the economy had to experience a large number of endogenous cycles of recession and recovery. Macroprudential policy has been in active development over the past decade in addition to prudential regulation. 


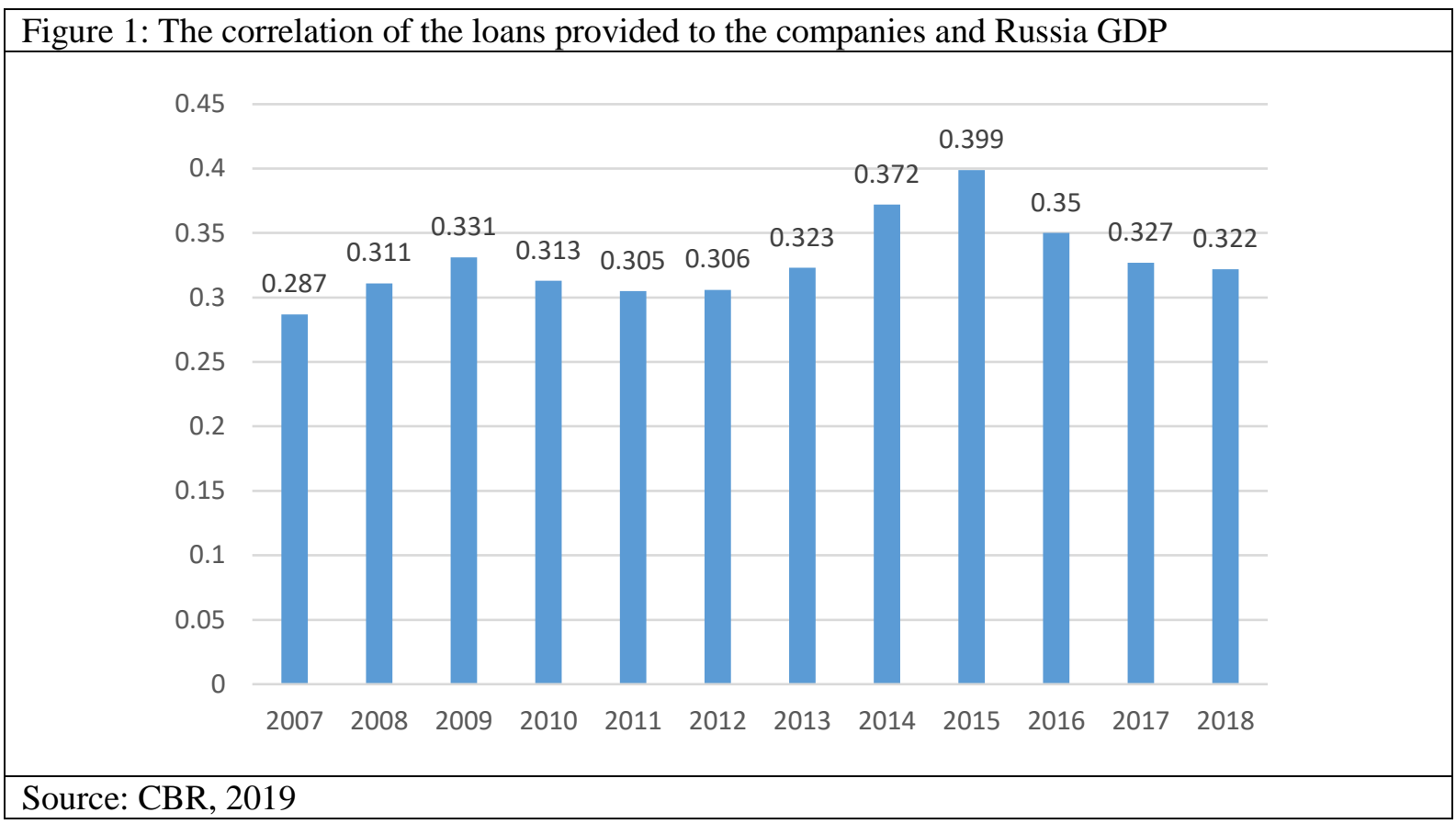

Some of the country's macroprudential instruments were already used back in the $1990 \mathrm{~s}$, but macroprudential policies became particularly widespread after the global financial crisis of 2007-2009, which revealed the shortcomings in the regulatory policies of the leading powers (Alessi, 2014). It made it clear that the price stability, supervision, and regulation of individual financial institutions are not sufficient to ensure the stability of a financial system as a whole.

The implementation of similar strategies by many companies that aim at using short-term market financing and over-the-counter derivatives and that are excessively dependent on credit rating agencies has led to the accumulation of large-scale system imbalances and significant losses on the part of taxpayers, when those risks substantialized. The goal of a macroprudential policy is to prevent these phenomena-after all, it is geared towards maintaining financial system stability. Inversely to the traditional prudential regulation, the macroprudential approach is sensitive to the interrelations that exist between financial institutions and to the possible effects of "contamination".

Macroprudential policies can be identified as the use of prudential instruments (e.g., capital adequacy ratio) in order to reduce systemic risks in the financial sector as a whole or in its individual segments. These risks bespeak the market's failure to provide financial services as a result of serious deficiencies in the financial sector (or its segments), which produces adverse effects on the real economy.

The seventh factor consists in the high volatility of cryptocurrency when compared to traditional currencies - this may endanger a national financial system. This volatility affects the economy by reassessing the debt and wealth effect (the Pigou effect).

A drastic shift in the exchange rate of the ruble against foreign currencies has a serious impact on the national economy. Similarly, the volatility of cryptocurrency rates affects interest rates. The depreciation of the ruble has led to the revaluation of debts denominated in foreign currencies, which means a considerable increase of the debt repayment level that is not secured by cash flow. An additional demand for borrowed funds, unsurprisingly escalated inflation, and increase of counterparty risks raise equilibrium rates on the debt market. Similar effects are observed when cryptocurrencies are over-valued (Glick, 1999). Moreover, if imports (of goods or services with cryptocurrency outlays) are reimbursed in cryptocurrencies, this overvaluation will also affect inflation expectations that are included in nominal rates. However, a cryptocurrency is able to produce effects only if its share in the liabilities and assets owned by Russian residents is significant (UIISS, 2019).

The volume of cryptocurrency in the global financial system is still insufficient to become a common means of payment. The ratio of the cryptocurrency total capitalization to the M2 global money supply is only $0.5 \%$ ( $17 \%$ to the US dollar money supply), while an accurate assessment of the share of cryptocurrency in the country's cash reserve is a complex task: the market is too opaque, most users are anonymous, and most dealings are trans-border. 


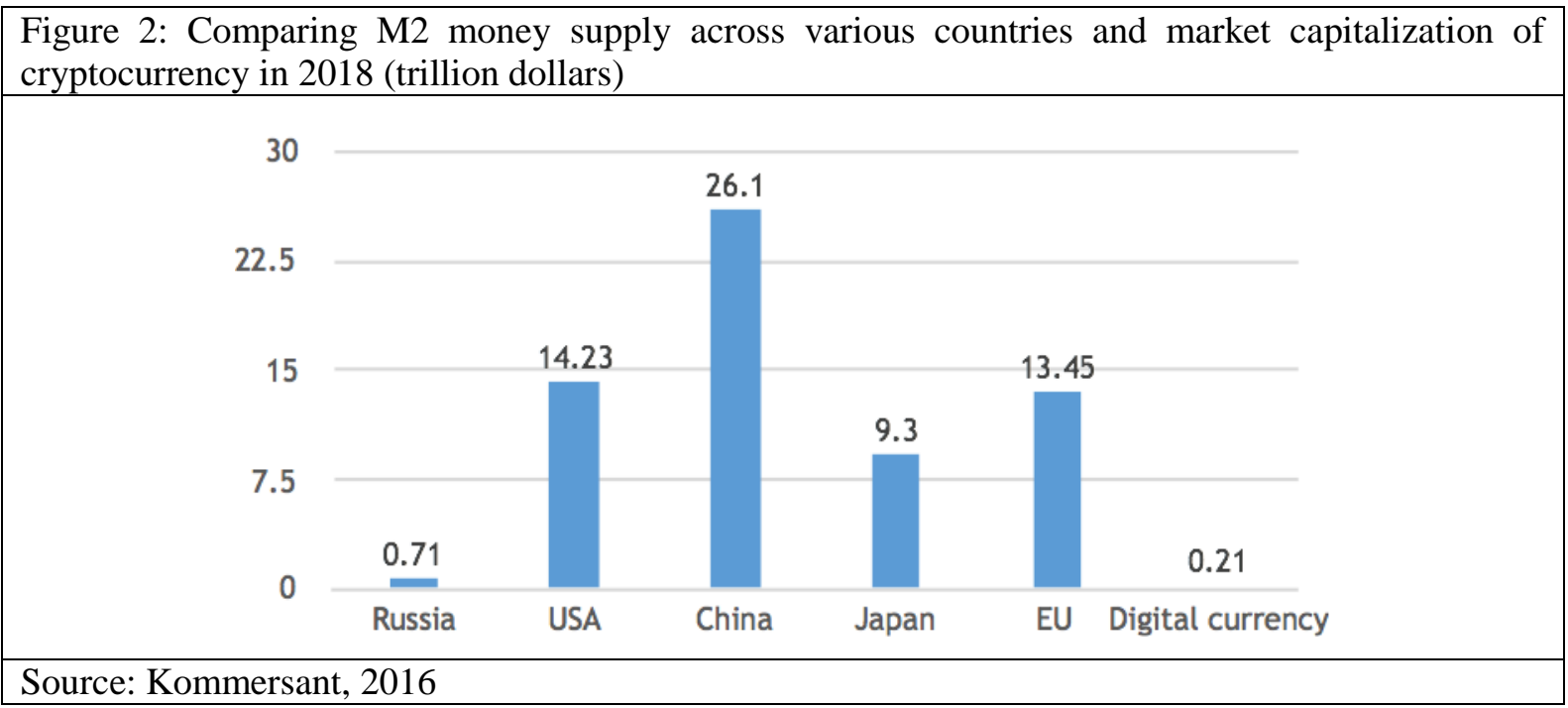

The share of cryptocurrency in Russia is estimated as 1-2\% of the total money supply.

Below are the factors that may propel the growth of this share in the Russian context:

- cryptocurrency's capital gain on the global scale;

- official recognition of cryptocurrencies as calculation units in Russia or abroad;

- liberalization of the regulatory regime to allow ICO and payments in cryptocurrencies.

This growth may be, however, restrained in view of the following:

- technological complications of the cryptocurrency market (80\% of bitcoins as per the volume of the original allowed protocol have been now mined; the distributive nature of the blockchain storage means significant energy consumption for recording new transactions, while creating new records in the blockchain involves complex calculations that take too long and, as a result, limit the processing speed);

- cryptocurrency's limited ability to compete with traditional currencies due to the lack of security and the rigidity of legal frameworks in many countries;

- cryptocurrency user's increased vulnerability to hacker attacks and high costs of prevention.

\section{Conclusion}

The analysis that we have carried out in the article focuses on the interrelation and interaction of financial markets with the financial cycles of the national economy.

A review of Russian and foreign literature provides a various understanding of problems of financial markets, financial cycles and their interaction. Of course, most modern economists say that it is necessary to study financial cycles in addition to economic cycles. It is undeniable that financial markets influence the formation of financial ups and downs with the help of various instruments such as stocks, loans, and exchange rates. It should also be noted, that many scientists study the features of the financial market through its individual sectors: banking, stock, etc.

The temporal transformations of financial cycles can be approached as periodic fluctuations of financial leverage levels. We have also given due consideration to the effects produced by shadow banking on financial cycle fluctuations in the context of a national economy. Another aspect that we have touched upon is determining the financial cycle phases in relation to the volatility rate of cryptocurrency as compared to traditional currencies. Redemption of shares and increase in the share of borrowed funds in large corporations are hereby viewed as the main instigators of financial recessions. Special attention needs to be paid to macro-industrial policies as regulators of the financial cycles of the national economy.

\section{References}

Alessi, L. (2014). Retrieved from the website of the Europian central bank: https://www.ecb.europa.eu/events/pdf/conferences/140623/Vasicek-et-al_Comparing-Different-Early-Warning-Systems.pdf Borio, C. (2015). BIS management speeches. Retrieved from The Bank for International Settlements: http://www.bis. org/speeches/sp151124_slides.pd 
CBR. (2019). Performance indicators of credit organizations. Retrieved from the website of the Central Bank of the Russian Federation: https://www.cbr.ru/statistics/?PrtId=pdko_sub

Fabozzi, F.I, F. Modigliani, F. J. Jones. (2010). Foundations of financial markets and institution. PrenticeHall.

FSSS. (2019). The efficiency of the Russian economy. Retrieved from the website of the Federal state statistics service: https://www.gks.ru/folder/11186\#

Glick, R. R.-0. (1999). Pacific Basin Working Paper Series. Retrieved from the website of the Federal Reserve Bank of San Francisco.

Kommersant. (2016). Cryptocurrency will give the Russian meaning. Retrieved from the website of the Kommersant publishing house: https://www.kommersant.ru/doc/3002854

Koptelov, I. (2017.). The problem of managing Russia's economic growth: myths and reality. Bulletin of Chelyabinsk State University, 90-95. Retrieved from Bulletin of Chelyabinsk State University.

Lee, C. (2013). Encyclopedia of Finance, Second Edition. Springer.

Mankiw, N. G. (2011). Principles of Economics, Sixth Edition. Cengage Learning,.

Mishkin, F. S., Eakins S. (2017). Financial markets and institutions.

Plasil, M., Seidler J. (2013). Financial stability report. Retrieved from the website of The Czech National Bank.

Song Shin, H. (December 2013 г.). IMF Working Paper. Retrieved from The International Monetary Fund: https://www.imf.org/external/pubs/ft/wp/2013/wp132

UIISS. (2019). Professional participants of the securities market. Retrieved from the website of the Unified interdepartmental information and statistical system: https://www.fedstat.ru/indicator/38752

Zarubezhnov, E., Koptelov, I. (2018). Economic growth and analysis of the country's development through macroeconomic indicators . Bulletin of Chelyabinsk State University, 204-210. 